\title{
Application of the Clinical Nurse Career Path Pattern at Regional General Hospital in Aceh Province
}

\author{
Rinaldi $^{1}$, Mudatsir $^{2}$, Elly Wardani ${ }^{3 *}$ \\ ${ }^{1}$ Master Program in Nursing, Faculty of Nursing, Universitas Syiah Kuala, Banda Aceh, Indonesia \\ ${ }^{2}$ Asistant Professor Faculty of Medicine University of Syiah Kuala, Banda Aceh, Indonesia \\ ${ }^{3}$ Department of Nursing Management, Faculty of Nursing, Universitas Syiah Kuala, Banda Aceh, Indonesia
}

\begin{abstract}
Article History
Received: 08.12.2021

Accepted: 06.01.2022

Published: 08.01.2022

Journal homepage:

https://www.easpublisher.com

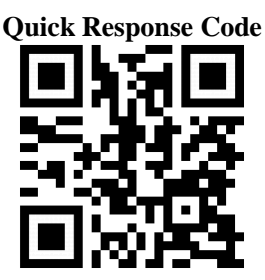

Abstract: Career path is a tiered pattern used to improve nurse performance and professional competence. Regional General Hospitals in Aceh Province were used as the research site to enhance nurse competence by implementing a clinical career path pattern. The Objective of the study was to determine the application of the clinical nurse career path pattern from the perspective of a nurse manager at a regional general hospital in Aceh Province. A qualitative method and phenomenological approach involving 10 correspondence was used with characteristics as nurse managers with a minimum educational background of Diploma III in nursing, and had worked for four years in a hospital. Then, the data were analyzed using the Colaizzi method. This research resulted in 3 themes that became obstacles in applying career path, including reduced implementation of clinical nurse re-credential, the lack of management support and commitment, and limited resources for applying career path pattern. The application of the pattern of professional clinical nurse career paths has not run optimally. Therefore, the hospital and nursing management should support and be committed to planning career path pattern. This include planning the HR needs, compiling and ratifying guidelines, conducting explicit socialization and re-credentials. They should also provide rewards through career development in the form of education and training following the competency gap of nurses.

Keywords: Carrier path, clinical nurses, Application, Hospital, Nursing.
\end{abstract}

Copyright (C) 2022 The Author(s): This is an open-access article distributed under the terms of the Creative Commons Attribution 4.0 International License (CC BY-NC 4.0) which permits unrestricted use, distribution, and reproduction in any medium for non-commercial use provided the original author and source are credited.

\section{INTRODUCTION}

Nurses as one of the most amount professional resources in hospitals, take apart responsibility for providing professional and safe services to patients (Hariyati, Igarashi, Fujinami, Susilaningsih, \& Prayetni, 2017). To provide safety and professional services as well as reduced the errors, nurses was required to work on standard practice according to the authority and competence in the field of practice that they are engaged in (American Nursing Association, 2015). Therefore, nurses need to improve their competence. Because a nurse that have competence is one of factor determinant for service quality in hospitals (Ratnamiasih, Govindaraju, Prihartono, \& Sudirman, 2012).

One of the efforts that hospitals can do to improve nurses competence with apply a career path pattern for clinical nurses. Career path is a tiered pattern that recognizes the experience, performance and expertise of nurses and provides opportunities for nurses to develop their performance and professionalism (Regulation of Minister of Health Indonesia No 40, 2017).

In Indonesia, clinical nurse career paths have been introduced since 2006, by the Indonesian National Nurses Association (PPNI) and the Indonesian Ministry of Health. And even there have been an implementation guidelines for the application of nursing career path in hospital there are 4 professional levels of nurses career namely; clinical nurses, manager nurse, educator nurse and research nurses. Currently, the career path pattern was focused its development is clinical nurse professional career path.

However, both private and government hospitals have not even implemented this program (Nurlina, Sekarwana, \& Somantri, 2018). Meanwhile, research shows that applying the clinical nurse career path pattern is very important for nurses and hospitals (Suroso, 2011; Amiruddin, Hariyati, \& Handiyani, 
2019). When this pattern is implemented in hospitals, it will impact nurse performance due to the less attention, causing nurses to move or even leave (turnover) (Duffield, Baldwin, Roche, \& Wise, 2014).

The Regional General Hospital (RSUD) implements a clinical nurse professional career paths pattern, starting with mapping for career level determination for old nurses who have worked with civil and non-civil servants (contracts). The hospital also conducted credentials and made a list of clinical authority descriptions and an official work assignment letter from the director for each nurse. However, sustainability and the re-credential assessment have not been implemented, but it has planned by the committee. Therefore, in its application hospitals should be able to do better planning because with a good planning of nurse career development program, will provide satisfaction to the need for nurse career which will have a positive impact on the hospital (Chang, Chou, \& Cheng, 2007).

According to various hospitals that have implemented the pattern, its application is inconsistent with the policies and standards (Istirochah \& Santoso, 2017). Although there has been a policy from the hospital to conduct career paths, its application has not moved the system because there are no grading documents, mapping, career path plots, and management teams. In addition, nurses' lack of understanding is also an obstacle in the process and application of career paths in hospitals (Mutinik, Saparwati, \& Rosidi, 2014). This makes nurses less enthusiastic to follow career path process. Based on the explanation above, it is necessary to know how to apply the clinical nurse career path pattern from manager's perspective for the Regional General Hospital in Aceh Province to identify the hindering problems.

\section{METHODS}

This is qualitative research with a phenomenological approach to obtain information from nurse manager's perspective regarding the hindering factors of applying the clinical nurse career path pattern. Ethical approval was obtained from the Ethics Committee of Syiah Kuala University with letter number 112018041120 dated November 23, 2020. The permission was also obtained from the director of the Regional General Hospital as the research location.

A total of 10 participants were nurse managers covering the nursing field, committee, and head of the room. The inclusion criteria are nurse managers with at least a D III nursing certificate and have worked for four years in the hospital. This research was conducted from December 2020 to March 2021. The data collection instruments consisted of the prominent researcher, interview guide, demographic data forms, cell phones, and voice recorders (smartphones). Before conducting the interview, the cell phone and voice recorder functioned properly to avoid missed information. After completing the interview process, the recording was immediately converted into a verbatim form.

Data collection was carried out concurrently with analysis referring to Colaizzi. These include reading interview transcripts, identifying meaningful participant statements, keywords, and sub-themes within the main theme (Streubert \& Carpenter, 2011).

\section{RESULTS}

The themes and sub-themes of the results are explained as follow:

Theme 1. The implementation of clinical nurse recredential has not been running optimally

This theme explains that the process of implementing the credential has not been running optimally. The application of career paths began in 2017. Following the preparations for accreditation assessments, all old nurses have received credentials, a list of clinical authority descriptions, and an official work assignment letter from the director. However, the data analysis identified that since four years of implementation, the credential process had not been carried out due to the unpreparedness of the nursing field in competency management. This indicates there is no clarity and schedule for implementing competency assessments. The nursing field's unpreparedness also contributes to compiling and preparing supporting documents for credentials because the committee still makes the plan. The following are some participant statements:

Table-1: Participant Data

\begin{tabular}{|l|l|l|l|l|l|}
\hline Initial & Age & Years of service & Gender & Education & Position \\
\hline P1 & $47 \mathrm{y}$ & $24 \mathrm{y}$ & $\mathrm{F}$ & Diploma III/Undergraduate of Nursery & $\begin{array}{l}\text { Head of committee/executive } \\
\text { nurse }\end{array}$ \\
\hline P2 & $38 \mathrm{y}$ & $12 \mathrm{y}$ & $\mathrm{F}$ & Undergraduate /Nurse & $\begin{array}{l}\text { Sub quality committee/head } \\
\text { of the room }\end{array}$ \\
\hline P3 & $37 \mathrm{y}$ & $12 \mathrm{y}$ & $\mathrm{F}$ & Undergraduate /Nurse & $\begin{array}{l}\text { Sub credential } \\
\text { committee/case manager }\end{array}$ \\
\hline P4 & $38 \mathrm{y}$ & $9 \mathrm{y}$ & $\mathrm{F}$ & Undergraduate /Nurse & Head of Room \\
\hline P5 & $35 \mathrm{y}$ & $6 \mathrm{y}$ & $\mathrm{F}$ & Undergraduate /Nurse & $\begin{array}{l}\text { Secretary of the Head of the } \\
\text { Committee }\end{array}$ \\
\hline
\end{tabular}


Rinaldi et al., EAS J Nurs Midwifery; Vol-4, Iss-1 (Jan-Feb -2022): 1-7

\begin{tabular}{|l|l|l|l|l|l|}
\hline Initial & Age & Years of service & Gender & Education & Position \\
\hline P6 & $32 \mathrm{y}$ & $4 \mathrm{y}$ & $\mathrm{F}$ & Diploma III/Undergraduate of Nursery & Head of Room \\
\hline P7 & $31 \mathrm{y}$ & $6 \mathrm{y}$ & $\mathrm{F}$ & Undergraduate /Nurse & $\begin{array}{l}\text { Head of Room/committee } \\
\text { member }\end{array}$ \\
\hline P8 & $37 \mathrm{y}$ & $14 \mathrm{y}$ & $\mathrm{F}$ & Diploma III of Nursery & $\begin{array}{l}\text { Head of Room/committee } \\
\text { member }\end{array}$ \\
\hline P9 & $31 \mathrm{y}$ & $9 \mathrm{y}$ & $\mathrm{F}$ & III of Nursery & Head of Room \\
\hline P10 & $34 \mathrm{y}$ & $7 \mathrm{y}$ & $\mathrm{M}$ & Diploma IV of Nursery & Head of Nursing Care \\
\hline
\end{tabular}

"The nursing committee is working on that... hopefully in the future, the system such as the promotion of the clinical nurses, credentials, and re-credentials will be more optimized" (P5).

"To increase career path from the nursing field, the plan should be appropriately made to show the time required for promotion and re-credential"(P6).

"Credentials are obtained due to the accreditation demands" (P9).

Theme 2. Lack of management support and commitment regarding the application of clinical nurse career paths

This theme explains the lack of support and commitment regarding implementing career paths. It emerged from 3 sub-themes: the absence of rules and policies for implementing career paths in hospitals, socialization related to the implementation of career paths, and lack of support in clinical nurse career development. The following is a description of the subthemes:

\section{a. The absence of rules and policies for the application of clinical nurse career paths in hospitals}

This sub-theme describes the absence of rules and policies in the form of guidelines and decrees from the director in applying career path. This indeed becomes an obstacle in the application of the credential. Career path is only formed due to the accreditation demands. The following is an excerpt from the participants' statement:

"lack of clarity on rules/regulations should be handled, hence, the leadership is more in line with the field to avoid the differences in the statements by a committee and the field" (P2).

"There is no policy from the director regarding applying career paths. For example, how many years of work with what certificate, can you go up a level or not ... it is more on the accreditation demands" (P3).

"From the director's policy, at first, there were only details of clinical authority, while other career path policies do not yet exist" (P6).

\section{b. Lack of socialization related to the application of career paths}

This sub-theme describes the lack of commitment to implementing career paths in hospitals because management has not carried out socialization.
This becomes an obstacle, impacting the lack of understanding of clinical nurses on implementing career paths. The following are some excerpts from participant statements:

"Junior (clinical nurses) in the field have not received information, or maybe it s contributed by the mistakes of nurse managers who do not socialize at all regarding career path, including the system and requirements" (Pl).

"I do not know the information, how it should be...for the process of career path...because there is still a lack of socialization" (P6).

"It is evidenced by many nurses who do not understand career path system due to lack of socialization. They just know about credential and career levels because of the accreditation demands" (P9).

\section{c. Lack of support for clinical nurse career development}

The lack of support for career development is due to the lack of budget for education and training. Education and training are not under the competency gap of clinical nurses. The following are some excerpts from participant statements:

"Clinical nurses should be facilitated through training to increase their level... A training was proposed according to the competency gap, but it is constrained by the cost" (P1).

"The education will be useful when it is financed. Besides, training and seminars should be often held always to update the gained knowledge" (P4).

"It is caused by lack of training, like the case in my room; I am the only one who has joined training... As for the other nurses not yet" (P9).

Theme 3. Limited resources for implementing the clinical nurse career paths

This theme explains the limitations of Human Resources (HR) for implementing career paths in hospitals. It emerged from 3 sub-themes: the implementation team for dual career paths, limited HR assessors, and the lack of number and qualifications of nursing staff in hospitals. 


\section{a. Implementation team for dual career paths}

This sub-theme describes that besides working on the committee, the multi-position nursing committee HR also works as the room head and holds other work programs. This impacts the delay in the implementation of credentials and re-credentials. The following is an excerpt from the participant statement:

"We work in this committee part-time because we have main jobs and this is only additional work... Therefore, I am a bit busy in the service, in the room, especially when there are several patients... I just finished my work at half-past 11, then in the rest of the time amid exhaustion, we just went to the secretariat of the committee" (P1).

"Amidst the obstacle at this time, we improve readiness, the limitations of human resources, because the nursing committee has another role, such as the head of the room,... hence, it is difficult to focus" (P5).

\section{b. Limited HR assessors in the hospital}

This sub-theme describes the limitations of human resources in hospitals where only one assessor assesses all nurses, hampering the implementation of competency assessments. The following is an excerpt from the participant statement:

"Because one assessor is currently in an unhealthy condition... then the committee cannot conduct re-credentials because the results of the assessment have not been submitted" (P2).

\section{c. Limited resources for nurses in hospitals}

This sub-theme describes the application of career paths that have not run optimally due to limited human resources for nurses. Therefore, clinical nurses' placement is inconsistent with the provisions. The following are the expressions of some of the participants:

"The new recruited nurse should not be placed in the surgery room....but, when there is a deficiency of personnel, the new nurse will be forced to be in the surgery room" (P3).

"The placement of nurses is inconsistent with career path, because of the limited staff who still do not fulfill the needs" (P8).

"The need for personnel is not sufficient... Therefore, it is rather difficult to place nurses according to their clinical experience" (P10).

\section{DISCUSSION}

\section{The Implementation of Clinical Nurse Re-Credential Has Not Run Optimally}

The credential aims to provide recognition and appreciation for the career achievements of nurses that implementation is carried out every 3 years (Regulation of Minister of Health Indonesia No. 49, 2013). The credentialing has not been implemented yet will hamper achievement career level of clinical nurse. This will affect the satisfaction of nurses at work. Career advancement of clinical nurses which are not paid attention tend to display low performance (Ratanto, Mustikasari, \& Kuntarti, 2013).

The implementation of the re-credential has not been carried out, due to the unpreparedness of the planning field in planning and managing the competency assessment. Career path implementation is inseparable from the management function, the planning should be carried out before the implementation of the career path is implemented. Nursing department as manager professional nurse is responsibility for managing nurse competency assessments (Regulation of Minister of Health Indonesia No 40, 2017).

In addition, the unpreparedness of the credentialing sub-committee regarding the supporting documents for credentialing is also an obstacle in the implementation of the credential. The nursing subcommittee through the credential sub-committee should have prepared earlier before the implementation of nurses career level is applied. One of the duties and responsibilities nursing committee through subcommittee recredential is to prepare a list of clinical authority and a white book as a requirement for clinical nurse career advancement (Regulation of the Minister of Health of the Republic of Indonesia No. 49, 2013).

Therefore, the nursing field and committee should plan before career path is performed. A good nurse career development program will satisfy the need for nurse career, positively impacting the hospital (Chang, Chou, \& Cheng, 2007).

Lack of management support regarding the implementation of career paths

a. There are no policies and rules for implementing career paths in hospitals

The research location has no support and commitment due to the absence of guidelines and decrees for implementing career paths in hospitals. This is an obstacle for implementing the clinical nurse career path, even though guidelines and decrees are needed as essential references that guide staff in carrying out their roles and functions.

The results are in line with previous research, where the problem in implementing career paths is because there are no policies and guidelines (Wahyu, Ika, \& Hartojo, 2016). Lack of support and commitment from the hospital causes nurses do not achieve a clear career path's expectation, leading to low satisfaction (Duffield, Baldwin, Roche, \& Wise, 2014). Leadership support can be provided through strengthening policies and providing necessary facilities for program implementation (Nelson, Sassaman, \& Phillips, 2008). 


\section{b. Lack of socialization on the implementation of career path}

The management's lack of commitment and follow-up in providing information shows that the implementation of career path has not been running optimally. These results follow Mutinik, Saparwati and Rosidi where the low understanding of nurses is also an obstacle to implementing career paths in hospitals (Mutinik, Saparwati, \& Rosidi, 2014).

To run a program, it needs to be informed before the implementation, hence, nurses know and are motivated to follow career path program. For example, Nelson and Cook stated that they are motivated to follow career paths related to knowledge and perceptions. Hospital management is responsible for sharing career information; hence, career paths should be communicated clearly and effectively to all relevant staff for advancement according to the plan (Marquis \& Huston, 2015). Socialization can be done in various ways ranging from the simplest to using advanced technology (Marwiati, 2018).

\section{c. Lack of management support for the clinical nurse career path}

In implementing career path, continuing education is needed to maintain and improve the competence of clinical nurses competence to overcome competency gaps. However, career development through education and training was not based on a competency gap due to the lack of budget. These results indicate that the application of clinical nurse career paths has not run optimally. According to Marquis \& Huston (2010), education and training programs should start from the orientation process to carry out staff development. Unfortunately, planning is directed at management development even though almost $80 \%$ of the organization's employees are non-management. This expression is supported by Reza's research (2015) that career path cannot be carried out without management support. Therefore, it requires strong support and commitment from the leadership and management to successfully implement the program (Afriani, Hariyati, \& Gayatri, 2017).

Hospitals should seek continuous education and training supported by awards to implement the professional clinical nurse career paths. In addition, recognition of work results and promotions can motivate them and provide job satisfaction (Kalibu, Hariyanto, \& Pusparahaju, 2014).

\section{Limited resources for implementing career paths}

The resource of implementing/nursing committee team in the hospital carries out dual-position credentials is limited. This will hamper the credential process because there are no unique resources in the credential sub-committee. These results follow research at the Padang Panjang City hospital. Besides working as a committee team, the multi-position nursing committee team also provides direct services in the room (Nengsih, Arief, \& Dorisnita, 2019). This will impact the workload, and the clinical nurse career path implementation is not optimal.

Then, besides the committee team with dualpositions, there is only one HR assessor in the hospital, hence, it also impacts assessors' workload and affects the delay in the implementation of competency assessments. Larasati stated that running a program optimally requires adequate human resources.

Dual-position and not up to standard resources hamper the credential in the form of delays because more dual positions and high workloads can reduce performance (Larasati, 2018). These shortages are caused by a lack of attention from the leadership; hence, leadership and management should pay more attention to these needs. According to research by An Australian Graduate of School of Management on 541 organizations, only $37 \%$ of institutions had HR planning systems based on scientific analysis. In addition, $41 \%$ did not have a good HR planning system, while the remaining $22 \%$ did not have any HR planning (Ilyas, 2004).

Based on the explanation above, the hospitals are recommended replanning to fulfill implementation resources, therefore, the program can run according to plan. However, suppose the human resources in the hospital are not sufficient, it is better to form an ad-hoc team to assist in the implementation of the committee's roles and duties (Regulation of Minister of Health Indonesia No. 49, 2013).

Furthermore, the hospital lacks human resources for nursing staff due to personnel calculation according to the workload and needs. Therefore, inadequate nursing resources result in incomplete program implementation. Managers should plan, organize, direct and supervise HR (Gillies, 2000). This follows Ilyas where hospital leaders should plan HR needs appropriately following the service function in each unit and room (Ilyas, 2004).

\section{CONCLUSION}

The results showed that the clinical nurse career path application has not been running optimally because re-credential has not been conducted. In addition, lack of support and commitment becomes an obstacle as indicated by the absence of rules and policies for implementing career paths in hospitals, socialization that has not been carried out, career development that has not been based on competency gaps, and limited resources.

Hospitals and management should reorganize the application of clinical nurse career paths by planning and fulfilling implementing resources following the needs. It can also be carried out by 
providing education and training following the competency gap.

\section{REFERENCES}

- Afriani, T., Hariyati, R. T., \& Gayatri, D. (2017). Dukungan atasan dan teman sejawat mempengaruhi ekspektasi perawat dalam penerapan jenjang karier. Jurnal Keperawatan Indonesia, 75-84.

- American Nursing Association. (2015). Nursing: Scope and Standards of Practice (3 ed.). Maryland: Nursesbooks.org.

- Amiruddin, Hariyati, R. T., \& Handiyani, H. (2019). Manfaat Jenjang Karier Bagi Staf Perawat Dan Rumah Sakit. Jurnal Kesehataan Poltekkes Kementerian Kesehatan RI Pangkal Pinang, 7(2).

- Benner, P. (1984). From Novice to Expert. The American Journal of Nursing, 82(3), 402- 407.

- Blakemore, S. (2010). Helping nurses hit their career. Nursing Mangement-United Kingdom, 16(19), 6-7.

- Burket, T. L., Feimlee, M., Greider, P. J., Hippensteel, D., Rorer, E. A., \& Shay, M. L. (2010). Clinical Ladder Program Evolution: Journey from Novice to Expert to Enhancing Outcomes. The Journal Education in Nursing, 41(8).

- $\quad$ Chang, P. 1., Chou, Y. C., \& Cheng, F. C. (2007). Carrer Needs Carrer Devolopment Programes, Organizational Commitmen and Turnover Intention of Nurses in Taiwan. Journal of Nursing Management, 15(8), 801-810. doi:10.1111/j.13652934.2007.00772.x

- Duffield, C., Baldwin, R., Roche, M., \& Wise, S. (2014). Job enrichment: creating meaningful career development opportunities for nurses. Journal of Nursing Management, 22(6), 697 - 706. doi:10.1111/jonm.12049

- Gillies, D. (2000). Nursing Management. Philadelphia: Saunders Company.

- Greenspan, M., \& Balasco, C. E. (2013). The role of practical wisdom in nurse manager practice: why experience matters. Journal of Nursing Managament, 21(7), 964-970.

- Griffiths, P., Ball, J., Drennan, J., James, L., Jones, J., Recio-Saucedo, A., \& Simon, M. (2014). The association between patient safety outcomes and nurse / healthcare assistant skill mix and staffing levels \&factors that may influence staffing requirements. University of Sounthampton.

- Hariyati, R. T. (2014). Perencanaan dan pengembangan dan utilisasi tenaga keperawatan. Jakarta: PT. Raja Grafindo Persada.

- Hariyati, R. T., Igarashi, K., Fujinami, Y., Susilaningsih, F. S., \& Prayetni. (2017). Correlation Between Career Ladder, Countinuiting Professional Devolopment and Nurse Satisfaction: A Case Study in Indonesia. International Journal of Caring Science, 10(3), 1490.
- Hittle, K. (2010). Understanding Certification, Licensure, and Credentialing: A Guide For the New Nurse Practitioner. Jurnal of Pediatric Health Care, 24(3), 203-206.

- Ilyas, Y. (2004). Perencanaan Sumber Daya Manusia Rumah Sakit, Teori, Metoda, dan Formula. Jakarta: Fakultas Kesehatan Masyarakat.

- Istirochah, \& Santoso, A. (2017). Gambaran Pelaksanaan Praktik Keperawatan Profesional Perawat KLinis III Berdasarkan kewenangan Klinis di Instalasi Rawat Inap Rsup Dr. Karyadi Semarang. Jurnal Program Studi Ilmu Keperawatan, 1-8.

- Kalibu, F. K., Hariyanto, T., \& Pusparahaju, A. (2014). Pengembangan Jenjang Karier Perawat Klinis di Unit Rawat Inap Rumah Sakit. Jurnal kedokteran Brawijaya, 28(1), 59-64.

- Kementerian Kesehatan RI. (2013). Petunjuk Pelaksanaan Jenjang Karier Perawat di Rumah Sakit. Jakarta: Direktorat Bina Pelayanan Keperawatan Dan Keteknisan Medik.

- Komisi Akreditas Rumah Sakit. (2017, 3 1). Standar Nasional Akreditasi Rumah Sakit. In K. A. Sakit, Standar Nasional Akreditasi Rumah Sakit. Jakarta Selatan. Retrieved from http:/kars.or.id

- Komisi Akreditasi Rumah sakit. (2012). Keperawatan Dalam Standar Akreditasi RS Versi 2012. In Persiapan Bidang Pelayanan Keperawatan terkait bidang keperawatan dalam standar Akreditasi RS.

- Larasati, S. (2018). Manajemen Sumber Daya Manusia. Yogyakarta: Deepublish (Group Penerbitan CV Budi Utama).

- Marquis, B. L., \& Huston, C. J. (2010). Kepemimpinan dan Manajemen Keperawatan; Teori dan Aplikasi (4 ed.). (Widyawati, Ed.) Jakarta: EGC.

- Marquis, B. L., \& Huston, C. J. (2015). Leadership Roles and Management Functions in Nursing Theory and Application. California: Wolters Kluwer.

- Marwiati. (2018). Deskripsi Implementasi Kompetensi Perawat sesuai Appointment di RSUD KRT Setjonegoro Wonosobo. Junal PPKM III, 314-326.

- Mutinik, Saparwati, M., \& Rosidi, M. I. (2014). Gambaran Persepsi Perawat Tentang Jenjang karier dI RSUD Tugurejo Semarang.

- Nelson, J., Sassaman, B., \& Phillips, A. (2008). Career ladder program for registered nurses in ambulatory care. Nursing Ekonomic, 2611, 393398.

- Nengsih, F., Arief, Y., \& Dorisnita. (2019). Clinic Nursing Experience in Implementing career path at RSUD Padang Panjang Hospital West Sumatera Indonesia in 2018. Indian Journal of Public Health Research \& Devolopment, 10(8), 2259-2263.5p.

- $\quad$ Nurdiana, N., Hariyati, R. S., \& Gayatri, D. (2019). Head nurse strategy for increasing nurse retention: 
A factor analysis. Enfermeria Clinica, 29(2), 560566.

- $\quad$ Nurlina, F., Sekarwana, N., \& Somantri, I. (2018). Sistem Pengembangan Jenjang Karier Perawat di Rumah Sakit. Jurnal Kesehatan Aeromedika Poltekes TNI AU Ciumbuleuit Bandung, 4(1).

- Peraturan Menteri Kesehatan RI. (2017). Pengembangan jenjang Karier Profesional Perawat Klinis. In P. j. Perawat, Pengembangan jenjang Karier Profesional Perawat Klinis (pp. 1-72). Jakarta: Menteri Kesehatan Republik Indonesia.

- Ratanto, Mustikasari, \& Kuntarti. (2013). Pengembangan Karier Sebagai Faktor Paling Mempengaruhi Kinerja Perawat Pelaksana. Jurnal Keperawatan Indonesia, 16(2), 114-119.

- Ratnamiasih, I., Govindaraju, R., Prihartono, B., \& Sudirman, I. (2012). Kompetensi SDM dan Kualitas Pelayanan. Trikonomika, 11(1), 49-57.

- Regulation of Minister of Health Indonesia No. 49. (2013). Tentang Komite Keperawatan Rumah sakit.

- Regulation of Minister of Health Indonesia No 40. (2017). Tentang Pengembangan Jenjang Karier Profesional Perawat Klinis.

- Streubert, H., \& Carpenter, D. R. (2011). Qualitative Research In Nursing Advancing The Humanistic Imperative.
- Sulistyawati, W., Sri Haryati, R. T., \& Kuntarti. (2016). Imlementasi Sistem Jenjang Karir dalam pelaksanaan Discharge Planning. Jurnal Ilmu keperawatan, 4(1), 34-43.

- Suroso, J. (2011). Penataan Sistem Jenjang Karir Berdasar Kompetensi untuk Meningkatkan Kepuasan Kerja dan Kinerja Perawat di Rumah Sakit. Ekplanasi, 6(2).

- Swansburg, R. C. (2000). Pengantar Kepemimpinan dan Manajemen Keperawatan Untuk Perawat Klinis. Jakarta: EGC.

- Tetuan, T., Browder, B., Ohm, R., \& Mosier, M. (2015). The Evaluation of a Professional Nurse Contribution Ladder in an Integrated Health Care System. AAACN Viewpoint, 35(3), 4-8.

- Undang-Undang Republik Indonesia. (2014). Nomor 38 Tentang Keperawatan. Jakarta.

- Wahyu, I., Ika, N., \& Hartojo. (2016). Pengembangan Jenjang Karir sebagai Strategi Mengelola Ketidakpuasan Kerja Perawat di Rumah Sakit. Jurnal Kedokteran Brawijaya, 29(3), 285290.

Cite This Article: Rinaldi, Mudatsir, Elly Wardani (2022). Application of the Clinical Nurse Career Path Pattern at Regional General Hospital in Aceh Province. EAS J Nurs Midwifery, 4(1), 1-7. 